\title{
Editorial
}

\section{Preface to Special Issue in Honor of the 80th Birthday of Professor Mingyuan He}

This special issue of Chinese Journal of Catalysis is dedicated to Professor Mingyuan He on the occasion of his 80th birthday, in recognition of his distinguished contributions to many aspects in the field of catalytic science and technology.

Professor He was born on February 8, 1940 in Shanghai, China. In 1961, he graduated from East China Textile Engineering Institute (now Donghua University), and earned his B.S. degree in applied chemistry. He then joined the Research Institute of Petroleum Processing, SINOPEC. During 1982-1984, he worked as a visiting scholar at the Northwestern University and the University of Texas at Austin. In 2000, he became an adjunct professor at East China Normal University, and established the Shanghai Key Laboratory of Green Chemistry and Chemical Processes in 2003. He has served as Chief Engineer and Vice Chairman of the Academic Committee at the Research Institute of Petroleum Processing. He was a Member of the Presidium and Deputy Director of Division of Chemistry at Chinese Academy of Sciences. He was the director of the Committee of Green Chemistry of Chinese Chemical Society. He was the Council Member of International Association of Catalysis Society and Vice Chairman of International Zeolite Association.

Professor Mingyuan He's research interests have focused on the new catalytic materials and oil-refining catalysts and processes. He developed many new methods for the synthesis of zeolites and refining catalysts, and also several novel refining processes, including the maximum isoparaffin process (MIP) with two reaction zones for enhancing the formation of isoparaffins in the gasoline. These novel catalysts and processes have significantly advanced the technologies for the catalytic cracking of heavy oils, increased the octane number of the catalytic cracking gasoline, and formed the new technologies for production of new-specification gasoline in China. Professor He is a pioneer in the area of green chemistry in China, and has actively promoted the development of green chemistry and chemical engineering. He was appointed to be the Principle Scientist by the Ministry of Science and Technology for the National Basic Research Project of China, entitled "Green chemistry for refining of oil and processing of basic organic chemicals", which has led to the breakthrough of green oil-refining and petrochemical technologies and their industrial applications. In order to address the critical problems with the low efficiency for the processing and utilization of fossil fuels and the consequently heavy emissions of green-house gases, in 2011, Professor He and coworkers for the first time put forward the new concept of green carbon science, which provides rational guidance for efficient utilization of carbon resources and carbon recycling toward the sustainable development of our society. To promote the further understanding on the green carbon science and development of green chemical processes, Professor He has made numerous efforts. For example, in recent years, he organized a number of symposia, forums and conferences, such as Xiangshan Scientific Conferences, themed "The scientific basis for the sustainable development of energy chemical industry: green carbon science and green hydrogen science", "Zeolites: hierarchy, selective catalysis and molecular engineering", "Green eco-environment and chemistry/chemical engineering", etc.

Because of his remarkable achievements in the fields of catalysis and petrochemical industry, Professor $\mathrm{He}$ has received numerous prizes, awards and honors. He was elected to the Chinese Academy of Sciences in 1995. He was recognized by the Second Prize of National Technological Invention in 1995 and the Prize for Scientific and Technological Progress of the Ho Leung Ho Li Foundation in 2001. He won the National Catalysis Achievement Award of China in 2012 and the National Zeolite Lifetime Achievement Award of China in 2019. He also received the insignia of Knight of the Ordre des Palmes Académiques in 2012 from French government, and an honorary doctorate from Ecole Normale Supérieure de Lyon in 2016.

This special issue has collected 15 invited articles, ranging from the synthesis of new zeolite catalysts, single-atom catalysis, electrocatalysis, and photocatalysis, to catalytic conversion of methane, carbon dioxide and biomass. These articles reflect to some extent the wide research interests of

DOI: 10.1016/S1872-2067(20)63585-9 | http://www.sciencedirect.com/science/journal/18722067 | Chin. J. Catal., Vol. 41, No. 7, July 2020 (C) 2020, Dalian Institute of Chemical Physics, Chinese Academy of Sciences. Published by Elsevier B.V. All rights reserved. 
Professor He, and the current worldwide research frontiers and progresses in the field of the catalytic science and technology. We are very grateful to the authors, the reviewers and the editorial office staff of Chinese Journal of Catalysis for their contributions and support.

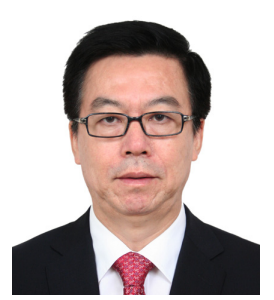

Prof. Zai-Ku Xie (谢在库)

China Petroleum \& Chemical Corporation, Beijing 100728, China

E-mail: xzk@sinopec.com

Prof. Zai-Ku Xie received his PhD degree from East China University of Science and Technology. He was elected academician of the Chinese Academy of Sciences in 2017. He is now the director of the science and technology department of SINOPEC and the executive deputy director of the science and technology committee of SINOPEC. He is now the vice president of the Catalysis Society of China from 2012, the vice president of the Chinese Zeolite Association from 2018, the vice president of Chinese Chemical Society from 2019, and the member of the Committee on Chemistry and Industry (COCI) of IUPAC from 2014. He was elected as a fellow of the Royal Society of Chemistry in 2013. His research interests focus on the preparation, characterization, and industrially catalytic conversion of novel zeolite catalysts. He has won many important awards, such as the first prize of National Science \& Technology Progress Award, second prize of National Technology Invention Award, Gold Medal of Chinese Patent, and Ho Leung Ho Lee Prize for Scientific and Technological Innovation.

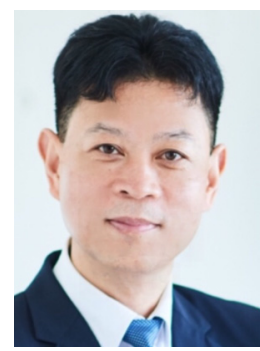

Prof. Bao-Lian Su (苏宝连)

State Key Laboratory of Advanced

Technology for Materials Synthesis and Processing, Wuhan University of Technology, Wuhan 430070,

Hubei, China

E-mail: baoliansu@whut.edu.cn

Prof. Bao-Lian Su, Member of the European Academy of Sciences,
Member of the Royal Academy of Belgium and Clare Hall Life Member, University of Cambridge. Prof. Su held "Belgian Francqui Chaire" in 2012-2013. He received his doctoral degree in 1992 from the University Pierre and Marie Curie, France and is an associated Professor at the University of Namur since 1995 and full Professor since 2002. He holds also a strategic scientist position at the Wuhan University of Technology. Prof. Su's current research fields include the synthesis, the property study and the molecular engineering of hierarchically porous materials, bio-integrated living and bio-inspired materials for catalysis, photocatalysis, artificial photosynthesis, nanotechnology, biotechnology, energy storage and conversion and cell therapy. He has received "First Class Invention Award of Sinopec" in 1993, the "China Patent Excellence Award" in 1994, the "Adolphe Wetrems Prize" of the Royal Academy of Belgium in 2007 and the "Distinguished Award for Novel Materials and their Synthesis" by the International Union of Pure and Applied Chemistry (IUPAC) in 2011 and the First Class Award of Science and Technology of Hubei Province in 2019 and the State Friendship Award of the Chinese Government in 2019.

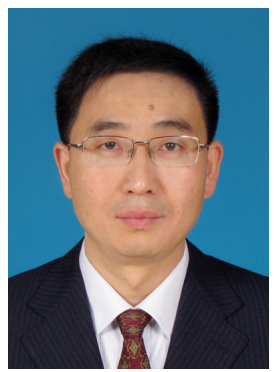

Prof. Haichao Liu (刘海超) College of Chemistry and Molecular Engineering, Peking University, Beijing 100871, China E-mail: hcliu@pku.edu.cn

Prof. Haichao Liu received his B.S. degree in 1990 and M.S. degree from Sichuan University in 1993, and his PhD degree from the Research Institute of Petroleum Processing in 1996. From 1997 to 2003, he worked as a postdoctoral research fellow at the University of Tokyo and the University of California at Berkeley. At the end of 2013, he joined the faculty of Peking University where he is now Changjiang Distinguished Professor of Chemistry. His research group focuses on the fundamental studies of the catalyst structures and reaction mechanisms, towards the design of heterogeneous catalysts and control of reaction pathways for selective conversion of biomass and its derivatives to chemicals, etc. He has been recognized with the National Science Fund for Distinguished Young Scholars of China (2008), The National Catalysis Prize for Young Scientists of China (2012), and The Enze Min Outstanding Contribution Award for Energy \& Chemical Engineering (2013). He has been an associate editor of Chinese Journal of Catalysis in 2014, and an editor of Journal of Catalysis in 2016.

\title{
《催化学报》庆祝何鸣元院士八十华诞专刊

\author{
谢在库 ${ }^{\mathrm{a}}$, 苏宝连 $\mathrm{b}$, 刘海超 $\mathrm{c}^{*}$ \\ a中国石油化工股份有限公司, 北京100728 \\ $\mathrm{b}$ 武汉理工大学材料复合新技术国家重点实验室, 武汉430070 \\ c 北京大学化学与分子工程学院, 北京100871
}

\begin{abstract}
摘要: 《催化学报》以本期专刊的出版庆祝何鸣元院士八十华诞, 表达对何先生五十多年来为我国催化及相关领域发展所 作出的卓越贡献的崇高敬意!

何鸣元先生1940年2月8日出生于上海, 1961年毕业于华东纺织工学院(现东华大学)应用化学专业, 同年进入石油化工 科学研究院工作至今. 1980-1984年作为访问学者赴美国西北大学化学系和美国得克萨斯大学奥斯汀分校化工系进行合 作研究. 2000年以来, 应邀兼任华东师范大学教授, 2003年领导建立上海市绿色化学与化工过程绿色化重点实验室. 何鸣 元先生担任过许多学术职务. 曾任石油化工科学研究院总工程师、学术委员会副主任, 中国科学院学部主席团成员、化学 部副主任, 中国化学会常务理事、绿色化学专业委员会主任, 国际催化理事会理事, 国际沸石分子篮协会副主席等.
\end{abstract}


何鸣元先生长期从事催化材料、炼油化工催化剂与工艺研究. 发明了一系列沸石分子篮合成新方法与炼油催化剂, 开 发了双反应区催化裂化增产汽油异构烷烃MIP工艺(Maximum Isoparaffin Process)等多个具有自主知识产权的新工艺, 为发 展我国重油裂化技术、提高催化裂化汽油辛烷值、开发新标准汽油生产技术等作出了突出贡献. 何鸣元先生是我国绿色 化学的奠基人之一, 他以国民经济可持续增长为目标, 大力倡导和推动绿色化学与化工学术研究与技术开发. 2001年担任 科技部国家基础研究重大项目(2001-2005) “石油炼制与基本有机化学品加工的绿色化学” 首席科学家, 推动了多项绿色炼 油与化工新技术的突破和工业应用. 针对碳资源利用过程中所面临的效率低、污染物排放严重等问题, 2011年, 何先生和 合作者从碳资源加工、利用和循环等全周期考虑, 提出了 “绿色碳科学” 的概念, 对碳资源的高效、清洁、循环利用具有 重要的指导作用. 近年来, 发起并主持了以 “可持续发展能源化工的科学基础: 绿色碳科学与绿色氢科学” “沸石分子筛: 等级特性、选择催化与分子工程” “绿色生态环境与化学化工” 等为主题的香山科学会议以及其它高水平学术会议, 为相 关学科指出了发展方向.

何鸣元先生获得了许多学术奖励和荣誉. 他于1995年当选为中国科学院院士, 曾获得国家发明二等奖(1995)、何梁何 利科学技术进步奖(2001)、中国催化成就奖(2012)、法国教育部棕榈叶骑士勋章(2012)、法国里昂高师荣誉博士学位(2016)、 中国分子筱终身成就奖(2019)等, 在国内外催化与石油化工界享有崇高的声誉.

本期专刊收录了 15 篇学术论文, 内容涉及新型分子篮催化剂的合成、单原子催化、光催化、电催化以及甲烷、二氧化 碳、生物质等碳资源的催化转化等, 一定程度上反映了何先生过去五十多年的研究兴趣, 并展现了当前国际催化科学与技 术研究的前沿和进展. 在此, 我们衷心感谢论文作者、审稿专家和《催化学报》编辑部等相关人员所给予的大力支持.

收稿日期: 2020-01-19. 接受日期: 2020-01-20. 出版日期: 2020-07-05.

*通讯联系人. 电话: (010)62754031; 电子信箱: hcliu@pku.edu.cn

本文的电子版全文由Elsevier出版社在ScienceDirect上出版(http://www.sciencedirect.com/science/journal/18722067). 